\title{
Okul PDR Hizmetleri Yönetmeliklerinin Beş Yıllık Kalkınma Planları ve MEB Şûra Kararlarına Uyumunun İncelenmesi
}

\author{
Șermin KÜLAHOĞLU ', Rüyam KÜÇÜKSÜLEYMANOĞLU ²
}

\begin{abstract}
Öz: Ülke kalkınması açısından oldukça önemli olan eğitim politikaları, kamu kesimi tarafından eğitimin yaygınlaştırılmasına ve geliştirilmesine yönelik alınan tedbirler olarak tanımlanabilir. Ülkenin eğitim politikası öncelikle kalkınma planlarında saptanır. Kalkınma planları, ülkenin ekonomik, sosyal ve kültürel alanlarda, uzun dönemde gerçekleştireceği büyümeyi ortaya koyan temel politika dokümanlarıdır. Kalkınma planlarının ana hedefi; vatandaşların refah seviyesini yükseltmek ve nitelikli yaşam koşullarına erişmesini sağlamaktır. Bu araştırmada, okul rehberlik ve psikolojik danışmanlık hizmetleri (PDR) yönetmelikleri, ilgili kalkınma planları ve Milli Eğitim şûra kararları, PDR meslek alanına ilişkin amaç ve görev tanımları açısından yaklaşımlarındaki benzerlik ve farklılıklara bakılmış ve birbirleriyle uyumları incelenmiştir. Araştırmada nitel desenli doküman analizi tekniği kullanılmış olup 11 kalkınma planı, 5 MEB yönetmelik ve yönergesi ve 2 Milli Eğitim Şûrası incelenmiştir. Çalışmanın sonucunda Milli Eğitim Bakanlığı’nın, okul PDR hizmetlerine yönelik hazırladığı yönetmeliklerde ve tavsiye kararı aldığı şûralarda, kalkınma planlarının kararlarına duyarlı ancak, kendi bakanlığı tarafından yapılmış önceki planlama ve düzenleme çalışmalarıyla uyumlu, destekleyici ve kavram birliğini gözeten bir tutum izlemediği saptanmıştır.
\end{abstract}

Anahtar Sözcükler: Okul Rehberlik ve Psikolojik Danışmanlık Hizmetleri Yönetmelikleri, Milli Eğitim Şûraları, Beş Yıllık Kalkınma Planları, Eğitim Politikası

\section{Compliance of School Psychological Counselling and Guidance Services Regulations with Five Year Development Plans and National Education Council Decisions}

\begin{abstract}
Education policies, which are very important for the development of the country, can be defined as the measures taken by the public sector for the dissemination and development of education. The education policy of the country is determined primarily in development plans. Development plans are the main policy documents that reveal the long-term growth of the country in economic, social and cultural fields. The main goal of development plans is to make citizens happy and prosperous. In this study, the similarities and differences in the approaches of school psychological counselling guidance services regulations, related development plans and National Education Councils in terms of purpose and job descriptions in the field of school guidance and psychological counseling were examined and their compatibility with each other was examined. In this research, qualitative patterned document analysis technique was used and 11 development plans, 5 Ministry of National Education regulations and directives and 2 National Education Councils were examined. As a result of the study, it was determined that the Ministry of National Education was sensitive to the decisions of development plans in the regulations and councils made for school guidance and psychological counselling services, but did not follow a supportive and unified conceptual approach in line with the previous planning and regulation studies made by its ministry.
\end{abstract}

Keywords: School Guidance and Psychological Counselling Services Regulations, National Education Councils, Five-Year Development Plans, Education Policy 
1950'li yıllardan itibaren Türk eğitim sisteminin gündemine girmiş olan okul psikolojik danışmanlık ve rehberlik (PDR) hizmetlerinin, 70 yılı aşan geçmişine rağmen, amaç ve işlevi konusundaki tartışmalar halen güncelliğini korumaktadır (Özyürek, 2007; Pişkin, 2006). Alana ilişkin kavramlar, PDR hizmetlerinin işlevleri, sınırları, alan çalışanlarının rol, kimlik, görev ve sorumlulukları üzerine algı ve anlayış farklılıkları ve uzlaşmazlıklar maalesef henüz aşılamamıştır (Doğan, 1991; Korkut, 2007; Özyürek, 2007; Şahin,2012). "Rehberlik mi psikolojik danışma mı, rehber öğretmen mi, psikolojik danışman mı?" sorularına yanıt arayan tartışmalar halen sürmektedir (Dağlı, 2014; Özyürek, 2007; Tuzgöz ve Keklik, 2012). Okul PDR hizmetlerinin amaçları, yöntemi, çalışma düzeni ve alan çalışanlarının görev, yetki ve sorumluluklarına ilişkin usul ve esasları düzenleyen PDR hizmetleri yönetmeliklerinde de bu belirsizliklerin sürdüğü görülmektedir. Son olarak, 10 Kasım 2017 tarihli Millî Eğitim Bakanlığı (MEB) Rehberlik Hizmetleri Yönetmeliği'nde, yönetmeliğin adından ve içeriğinden 'psikolojik danışma' kavramı çıkarılarak okul PDR hizmetlerinin sınırları daraltılmıştır. Bu değişiklik akademik çevreler ve alan çalışanları tarafından şiddetle eleştirilmiş, yönetmeliğin çağdaş uygulamaları gözeten biçimde yeniden değiştirilmesi, en azından eski haline dönmesi talep edilmiştir (Gümüss, 2018; Üstüner, 2018). Eğitim sistemi içinde yer alan PDR hizmet alanının amaçlarını ve rollerini belirleyen resmi kurum olan MEB'in, bu tür politikalarının meslek alanının gelişimini kesintiye uğrattığ1 öne sürülmektedir (Akay, Türk, Mercan ve Urtekin, 2019; Gümüş, 2018; Nas, 2018; Üstüner, 2018). Bu sıkıntıların, meslek alanına olduğu kadar içinde yer aldığı eğitim sistemine ve dolayısıyla, ülke kalkınmasına da olumsuz yansımalarının olması kaçınılmazdır.

Bir ülkenin eğitimi, ülke kalkınma stratejileri için önemli bir araçtır. Türkiye'nin kalkınma stratejileri, beş yıllık kalkınma planları ile karara bağlanmaktadır. Beş yıllık kalkınma planları, Türkiye'nin ekonomik, sosyal ve kültürel alanlarda, uzun dönemde gerçekleştireceği büyümeyi ortaya koyan ülke kalkınmasıyla ilgili alanlarda, sorunları saptayıp, hedefler ve amaçlar belirleyerek geleceğe yönelik ön görüş oluşturan, temel politika dokümanlarıdır. Beş yıllık kalkınma planları, 1960 yılından bu yana, eski adıyla Devlet Planlama Teşkilatı (DPT), 2011'den bu yana yeni adıyla Kalkınma Bakanlığı'na dönüştürülmüş¹ olan kurum tarafından hazırlanmaktadır. İlk kalkınma planı, 1963 yılında yürürlüğe girmiş ve son olarak 2019-2023 dönemini kapsayan11. Kalkınma Planı hazırlanmıştır. Kalkınma planlarında, ekonomik ve sosyal konular başta olmak üzere, birçok konuya ilişkin düzenlemeler yer almaktadır. Tüm kalkınma planlarında eğitim başlığı yer almıştır. İlk kalkınma planında yer alan "Eğitim, istenilen bir yaşama düzenine ulaşmak çabası olan kalkınmanın en etkili araçlarından biridir." ifadesinde de belirtildiği gibi bir ülkenin kalkınma stratejileri, eğitim politikalarından ayrı değerlendirilemez (Küçüker, 2012). Bu bağlamda, kalkınma planlarının amaçlarından birisi de eğitimin planlanmasıdır (Taş, 2007). Eğitim hizmetinin nasıl sunulacağı, eğitime ilişkin kaynakların nasıl sağlanacağı ve ne şekilde kullanılacağı ile devletin eğitimdeki rolünün ne olacağı konularında belirlemeler ortaya koyan kalkınma planı kararlarının, MEB hizmetleriyle ilgili düzenlemelere yansıtılması ve bu şekilde planlı kalkınmanın sürdürülebilir şekilde devam etmesi beklenmektedir. Kalkınma planlarının, kamu sektörü için emredici özelliği de bu koordinasyonu gerektirmektedir. Kalkınma planları yanında, Milli Eğitim (ME) şûraları da eğitim planlamasının önemli bir yönünü oluşturmaktadır. Şûra kararları Türk eğitim sistemine yol gösterici nitelikte olan yasal metinlerdir. Hesapçığlu (2001) şûra kararlarını eğitim planlaması dokümanları olarak nitelendirmektedir (akt. Küçüker, 2012). Kalkınma planları kararlarının şûra kararları ve yönetmeliklerle uyum içinde uygulamaya konulması, yani bu üçlü arasında bütünleyici bir bakış ve eşgüdümün sağlanması, eğitimle ilgili işleyişin gelişimsel yönelimi açısından önemlidir.

Alan yazında, kalkınma planlarının milli eğitim sistemine ilişkin kararlarını inceleyen araştırmalar, kalkınma planlarında eğitime ilişkin görüşülen konuların ve belirlenen hedeflerin, daha sonraki planlarda da tekrar edildiğini, bu durumun sorunlara çözüm bulunamadığının ve arzulanan hedeflere ulaşılamadığının bir göstergesi olduğunu belirtmektedir (Altundemir, 2012; Dağhan, Kalaycı ve Seferoğlu, 2011; Küçüker, 2012; Yıldız ve Yıldız, 2016). ME şûra kararlarını kalkınma planlarındaki eğitime ilişkin hedefler çerçevesinde değerlendiren çalışmalar, bu ikisinin kendi içinde ve birbiriyle her zaman tutarlı ve örtüşen kararlar ortaya çıkarmadığını, ME şûralarında da tekrara düşüldüğünü veya farklı şûraların kararları arasında tutarsızlıklar olduğunu ortaya koymaktadır (Çoruk, 2019; Güven, Alagöz ve Baldan, 2016; Paksoy, 2011). ME şûralarında alınan kararların bir kısmının uygulandığı, bazılarının kalkınma planlarıyla ilişkilendirildiği, genelde 
şûraların, eğitim politikalarının oluşmasında öneriler ortaya koymaktan öteye gidemediği belirtilmektedir (Tofur, Aypay ve Yücel, 2016).

Kalkınma planlarını PDR alanı açısından incelemiş olan iki çalışma bulunmaktadır. Tan (1990) kalkınma plânlarının PDR alanına bakışını, öğrenciyi daha çok ekonomik bir varlık olarak ele aldığı ve rehberliği, öğrencilere iyi bir üretici olmaları için sunulacak hizmetlerden ibaret saydığı için eleştirmiştir. Halmatov (2014, s. 71-75) Türkiye'de PDR'nin gelişim süreci konulu doktora tezinde 4. kalkınma planına ve 11. ME şûrasına kadar ki süreçte, rehberlik ile ilgili alınan kararlara kısaca değinmiş ve ME şûralarında mesleki ve eğitsel alanlarda yöneltme hizmetlerine daha fazla ağırlık verildiğini saptamıştır. ME şûralarında PDR alanına ilişkin kararları inceleyen çalışma sayısının da iki ile sınırlı kaldığı görülmektedir. Doğan (1991) 12. ME şûrasına kadar olan incelemesinde, şûraların rehberlik alanını geliştirdiği sonucuna ulaşmıştır. Şahin (2012) ise 18. ME şûrasına kadar, PDR ile ilgili olarak alınmış olan kararlarda, konu dağılımı ve unvan konusunu incelemiş, şûraların yaklaşık yarısının eğitsel PDR ile ilgili olduğu ve psikolojik danışmanlar için ağırlıklı olarak rehber öğretmen unvanı kullanıldığını ortaya koymuştur. PDR yönetmelikleri üzerine yapılan araştırmalarda daha çok en son yürürlüğe giren PDR yönetmeliğinin eleştirilmesi konusuna odaklanıldığı görülmektedir. Son PDR yönetmeliğinin, 2020'li yılların alan yazınındaki kavramlaştırmaya uygun olmadığı, okul PDR hizmetlerinin kapsayıcı bir şekilde ele alınmadığı yönünde yoğun eleştiriler alması, çağdaş ve gelişimsel anlayışla, alan çalışanlarının yetkinliklerini ve yürütülen hizmetleri dar bir alana sınırlamayan, mesleki etik ilkelerle uyumlu hizmet sunulmasını sağlayan bir yönetmeliğin hazırlanmasına gerek olduğu savunulmuştur (Eğitim-Sen, 2017; Gümüş, 2018; Nas 2018; Üstüner, 2018). Hizmet alanıyla ilgili tüm faaliyetlerin planlanması, yönetimi ve değerlendirmesine yönelik düzenlemeleri içeren hizmet yönetmeliği, MEB'in kavram ve uygulama olarak PDR alanını ele alışını, PDR hizmetlerine bakışını ve verdiği önemi yansıtmaktadır. Hizmet yönetmelikleri, kalkınma planlarının doğrudan uygulamaya geçirilmesinin bir aracı olmasa da kalkınma planı kararlarının ve milli eğitim politikalarının uygulamadaki düzenlemeleri ile ilişkilidir.

Türk Milli Eğitim Sistemi'nin oluşturulmasında başlıca belirleyiciler; ilgili yasalar, kalkınma planları, ME şûraları, alanda görev ve işleyiş ile ilgili usul ve esasları düzenleyen yönetmelik, genelge ve yönergelerdir (Şişman ve Taşdemir, 2008). Kalkınma planları, eğitimde geleceğe yönelik hedeflerin oluşturulduğu yasal metinlerdir. MEB, kalkınma planlarında öncelikle yer almasını gerekli gördüğü hizmet ve tedbirleri saptar, bunlarla ilgili temel politikaları belirler ve Devlet Planlama Teşkilâtına gönderir. MEB'in temel politikaları ise Türk eğitim sistemine tavsiye kararları ile yön vermesi beklenen ME şûralarında ele alınır. Sonuç olarak, ME şûralarında, Türk millî eğitimini düzenlemek ve geliştirmek amacıyla üretilen görüşlerin, milli eğitim politikalarını oluşturması, bu politikaların kalkınma planları kararları içinde yer alması ve bunların uygulamada yönetmelik gibi ilgili düzenlemelere yansıması şeklinde bir döngü ortaya çıkar. Bu yapıların hem kendi içlerinde tutarlı hem de birbirini destekleyen nitelikte olması, kararlılık ve süreklilik göstermesi önemlidir (Taş, 2007; Yıldız ve Yıldız, 2016). PDR hizmetlerinin yapılandırılması, uygulanması ve geliştirilmesi ile ilgili çalışmaların bütüncül bir bakış açısıyla ele alınarak eşgüdüm içerisinde yürütülmesi gerekmektedir.

Buradan hareketle, bu araştırmada, okul PDR yönetmeliklerinde PDR hizmetlerinin amaç ve işlevine ilişkin ortaya çıkan anlayışın, kalkınma planları ve ME şûra kararlarındaki anlayışla uyumunun tarihsel bir perspektifle sorgulanması amaçlanmıştır. Okul PDR hizmetleri yönetmeliklerinin, yönetmeliğin yayımlandığı dönemin kalkınma planları ve o dönemde yapılan MEB şûralarının, PDR meslek alanına ilişkin amaç ve görev tanımlamalarına bakılmış, yaklaşımlarındaki benzerlikler ve farklılıklar üzerinden birbirleriyle uyumları incelenmiştir. Çalışma kapsamında, MEB'in, 2021 tarihine kadar yürürlüğe koymuş olduğu PDR yönetmelikleri ve ME şûraları, içinde yer aldıkları dönemin kalkınma planları ile ilişkisi ele alınarak aralarındaki uyum sorgulanmıştır. Örneğin, 1985 Rehberlik Hizmetleri Yönetmeliği Beşinci Beş Yıllık Kalkınma döneminde (1985-1989) yürürlüğe girmiştir. Aynı kalkınma dönemi içinde 18-22 Haziran 1988 tarihlerinde 12. ME şûrası gerçekleştirilmiştir. Bu bağlamda, Beşinci Beş Yıllık Kalkınma Planı, 1985 Yönetmeliği ve 12. ME şûrası, PDR hizmetlerine bakış açısından, karşılaştırmalı olarak incelenmiştir. 


\section{Yöntem}

Nitel araştırma yöntemlerine göre tasarlanan bu çalışmada, yazılı belgelerin içeriğini titizlikle ve sistematik olarak analiz etmek için doküman incelemesi kullanılmıştır. Mevcut kayıt ya da belgelerin, veri kaynağı olarak sistemli incelenmesi olarak ifade edilen doküman incelemesi, araştırılacak konular hakkında bilgi içeren yazılı materyallerin analizini kapsar (Yıldırım ve Şimşek, 2006). Doküman analizi sürecini Altheide (1996); dokümanlarda dâhil edilecek kriterleri belirleme, doküman ve veri toplama, temel analiz alanlarını belirleme, dokümanı kodlama, doğrulama ve analiz etme olarak sınıflamaktadır. Analiz sürecini yönlendiren birbiriyle ilişkili iki ilke tarafsızlık ve güvenilirliktir. Bir analiz, aynı belge setini benzer koşullar altında analiz etme fırsatı verildiğinde başka bir okuyucunun aynı genel sonuca ulaşması durumunda güvenilir olarak kabul edilir (Altheide, 1996). Dokümanlara ulaşma, orijinalliğini kontrol etme, dokümanları anlama, veriyi analiz etme, veriyi kullanma aşamalarına göre yapılır (Yıldırım ve Şimşek, 2006). Başarılı bir doküman incelemesinin temel şartı, konuya ilişkin belgelerin bulunması, incelenmesi ve belli durum ya da görüşleri ortaya çıkartacak bir senteze varılabilmesi için gerekli düzenlemelerin yapılabilmesidir (Karasar, 2007). Bu çalışmada, okul PDR hizmetlerini düzenleyen toplam dört yönetmelik, bu yönetmeliklerin her birinin yürürlüğe girdiği yılları içine alan dört kalkınma planı ve 2 ME şûrası ele alınmıştır. Söz konusu dokümanlara Türkiye Cumhuriyeti Cumhurbaşkanlığı Strateji ve Bütçe Başkanlığı web sayfası ile Talim ve Terbiye Kurulu Başkanlığı web sayfasından ulaşılmıştır. İncelenen dokümanlar aşağıda sıralanmıştır:

1. İlk Rehberlik ve Araştırma Merkezi Yönetmeliği (12.02.1968)

2. Orta Dereceli Okullarda Rehberlik Servislerinin Kuruluşu ve Görevleri ile İlgili Bazı Esaslar Genelgesi $(10.06 .1970)$

\section{Sekizinci ME Şûrası (28 Eylül-3 Ekim 1970)}

4. İkinci Beş Yıllık (1968-1972) Kalkınma Planı

5. Rehberlik Hizmetleri Yönetmeliği (16.12.1985)

6. 12. ME Şûrası (18-22 Haziran 1988)

7. Beşinci Beş Yıllık (1985-1989) Kalkınma Planı

8. PDR Hizmetleri Yönetmeliği (17.04.2001)

9. İlköğretimde Yöneltme Yönergesi (02.07.2003)

10. Sekizinci Beş Yıllık (2001-2005) Kalkınma Planı

11. 2017- Rehberlik Hizmetleri Yönetmeliği (10 Kasım 2017)

12. Onuncu Beş Yıllık Kalkınma (2014-2018) Planı

\section{Verilerin Analizi}

Doküman incelemesi ile elde edilen araştırma verileri, betimsel analiz yöntemiyle analiz edilmiştir. Bu amaçla elde edilen veriler, önceden belirlenen temalara göre sistematik ve açık bir biçimde özetlenip, yorumlanarak betimlenir ve birtakım sonuçlara ulaşılır (Yıldırım ve Şimşek, 2006). Araştırma kapsamında, kalkınma planları, yönetmelikler ve şûra kararlarına ilişkin araştırma bulguları, önceden belirlenen alt başlıklar çerçevesinde gruplandırılarak analiz edilmiş, doğrudan alıntılarla verilmiş ve tablolar yardımıyla karşılaştırılmıştır.

\section{Araştırmanın Geçerlik ve Güvenirliği}

Araştırmanın iç geçerliğinde ele alınan kavramların ve araştırma sürecinde ulaşılan sonuçların birbirleriyle olan ilişkileri ve sunulan içerikle bir bütünlük sağlayıp sağlamadıkları ön plana çıkar (Maxwell, 1992). Bu bağlamda iç geçerliği sağlamak için kalkınma planları ME şûraları ve PDR yönetmeliklerinden elde edilen verilerin, araştırmanın içeriğiyle ilişkisi ortaya konularak yorumlamalara gidilmiştir. Dış geçerliğin sağlanması için belirlenen amaca uygun olarak, PDR yönetmelikleriyle ilişkili olan kalkınma planları ve ME 
şuraları ele alınmış; öte yandan araştırmanın deseni, çalışma grubu, verilerin toplanması ve analizi süreçlerindeki işlemler ayrıntılı olarak anlatılmıştır (Maxwell, 1992). Yapılan analizler ve elde edilen bulgular üzerinde, önce nitel araştırma alanında uzman bağımsız bir araştırmacıya gönderilmiş ve geri bildirim alınmış; daha sonra birisi PDR ve diğeri eğitim yönetimi alanında uzman olan makale yazarlarının, birbirlerine karşılıklı geri bildirimler vermesi yoluyla, araştırmanın güvenilirliği arttırılmaya çalışılmıştır (Glesne ve Peshkin, 1992; Roberts, Priest ve Traynor, 2006).

\section{Bulgular}

\section{Bulgu 1: İlk Düzenlemeler Çerçevesinde Okul PDR Hizmetlerine Bakış}

Aşağıda, 1968-70 yıllarında çıkarılmış olan PDR yönetmeliklerine yansıyan okul PDR hizmetlerine bakışın, dönemin kalkınma planı ve ME şûra kararlarıyla uyumuna bakılmıştır.

\section{Rehberlik ve Araştırma Merkezi Yönetmeliği}

Rehberlik ve Araştırma Merkezi (RAM) Yönetmeliği (MEB, 1968), Orta dereceli Okullarda Rehberlik Servislerinin Kuruluşu ve Görevleri ile İlgili Bazı Esaslar Genelgesi (MEB, 1970), İkinci Beş Yıllık (1968-1972) Kalkınma Dönemi içinde yürürlüğe girmiş ve bu dönemde 28 Eylül-3 Ekim 1970 tarihinde Sekizinci ME şûrası gerçekleştirilmiştir. Genelge ile okullarda rehberlik hizmet birimlerinin kurulması, geliştirilmesi ve bu konu için gerekli personelin işbaşında yetiştirilmesi ile ilgili çalışmalar düzenlenmiştir.

Türkiye' de 1995 yılında ilk merkezin özel eğitime muhtaç çocukları incelemek amacıyla açılmış olmasının etkisiyle, RAM Yönetmeliğinin özel eğitim hizmetlerine yönelik hazırlandığı görülmektedir. Yönetmelik metninde, merkezîn görevi başlığı altında, (MEB Rehberlik ve Psikolojik Danışma Hizmetleri Yönetmeliği, 2001, s. 5) "her kademedeki okullarda başarısızlığa uğrayan, ilkokullarda başarısızlığa uğrayan zekâca geri çocuklara (Karar 2) zekâca normalin üstünde olup da fevkalâde başarı ve üstün özel yetenek gösteren çocuklar (Karar 3) işitme, görme ve lisan arızalı öğrencileri (Karar 4) duygusal bozukluğu olan çocuklarla sakatlar (Karar 5), psikolojik ve sosyal yönden uyumsuzluğu ve ruhi kompleksleri olan çocukları (Karar 6) olmak üzere öncelikle ve ağırlıklı olarak özel eğitime muhtaç çocuklara hizmet vermek" anlayışıyla düzenlendiği görülmektedir. Yalnızca 8. maddede, "Okul ve meslek seçimi için gerekli çalışmaları yapar. Uygulanan genel kabiliyet, farklı özel kabiliyet ve ilgi testleri neticeleri ve yapılan mülakatlarla gerek çocuğa gerek veliye daha isabetli karar vermede yardımcı olur" mesleki yönlendirme amaçlı rehberlik hizmetine yönelik görev ifadesi yer almaktadır. Merkezin beş bölümü içinde, en çok sayıda görevin (Karar 45- 66 arası, Madde 22, s. 5) Özel Eğitim bölümüne verilmiş olması da RAMların özel eğitime muhtaç çocukların sorunlarına odaklı bakışla düzenlendiğini göstermektedir.

Okul PDR hizmetlerine yönelik Okul Grup Rehberliği Bölümünün görevleri (Madde 33- 44, Madde 12, s. 5) sıralamasında, okul PDR hizmetlerine bakış, öğrencileri tanıma (Madde 34), başarı sağlayamayan öğrencilere yardım (Madde 38), eğitim ve öğretimle ilgili güçlüklerin yenilmesi ve okullarda ruh sağlığı (Madde 39), seçmeli dersler (Madde 40), okul seçimi (Madde 35), iş ve meslek seçimi (Madde 36, 37) görevlerini yansıtmaktadır. 33 ile 41-44 arası maddelerde, okullarda rehberlik örgütünün kurulmasına ön ayak olmak, seminer, kurs ve konferansları desteklemek, üniversiteler ve diğer eğitim kurumları ile işbirliği yapmak, bölüm çalışmaları ile ilgili bibliyografya hazırlamak gibi bölüm hizmetlerini destekleyici çalışmalar açıklanmaktadır.

Sonuç olarak, Okul Grup Rehberliği'nin mesleki rehberlik görevleri arasında en ağırlıklı öneme sahip olduğu söylenebilir. PDR hizmetlerine bakışı yansıtan kavramların başarısız öğrencilere yardım, özel eğitime muhtaç öğrenciler, üstün zekâlı, engelli, uyumsuz, okul ve meslek seçimi, öğrencileri tanıma, eğitim ve öğretimle ilgili güçlüklerin yenilmesi ve okullarda ruh sağlığı olarak sıralandığ1 görülmektedir. Bu sıralamada, öncelikle sorunlu öğrencilere yardım, ardından da mesleki rehberlik hizmetlerine yönelik bir anlayış vurgulanmıştır. Merkezde görev yapacak elemanlar sıralamasında (Madde 75-96, s. 6-7), sosyal hizmet uzmanları ve merkez doktoru görevlendirmeleri yapıldığı görülmektedir. Alan çalışanları "rehber öğretmen" olarak adlandırılmış ve alması gereken eğitim ve görevleri açıklanmıştır (Karar 93, 94, s. 7). 


\title{
Orta dereceli Okullarda Rehberlik Servislerinin Kuruluşu ve Görevleri ile İlgili Bazı Esaslar Genelgesi
}

Orta dereceli Okullarda Rehberlik Servislerinin Kuruluşu ve Görevleri ile İlgili Bazı Esaslar Genelgesi (MEB, 1970) ile RAM'a bağlı okul PDR hizmetlerinin yapılandırıldığı ve bu anlamda tamamlayıcı olduğu görülmektedir. Bu genelge ile rehberliğin tanımı, amaçları ve gereği, okul rehberlik servisi kuruluş şeması, rehberlik programı rehberlik servisi personeli, rehberlik servislerinin çalışmaları ve bazı rehberlik teknikleri konularında düzenlemeler yapılmıştır.

Genelge metninin girişinde, okul PDR hizmetleri “Öğrencilerin yakından tanınmaları, kişisel, sosyal ve akademik problemlerine nüfus edilmesi, bu problemleri çözmelerinde kendilerine yardımcı olunması, daha üst öğrenim alanlarını seçmelerinde veya bir mesleğe yönelmelerinde rehberlik yapılması, okullarımızın önemli görevleri arasındadır" şeklinde tanımlanmaktadır. Rehberliğin tanımı, amaçları ve görevleri başlığı altındaki maddelerde, okul PDR hizmetlerini, kalkınma planındaki gibi, kişisel-sosyal ve mesleki gelişime yardım olarak gören tanımlamalar yer almaktadır. Bu tanımlamalar aşağıdaki gibidir (MEB Milli Eğitim Şurası, 1970, s. 294):

\begin{abstract}
...Bu hizmet kişinin bir bütün olarak kabil olabildiği kadar yakından tanınması ve onun kendi kendisini ve çevresini tanımasına yardımcı olunması, bu tanıma ve tanınmanın da kişinin ve toplumun yararına en iyi şekilde değerlendirilmesi için gerekli tekniklerin kullanışı ile yürütülür. Kişinin (öğrencinin) okul içinde ve dışında kişiliğinden gelen veya çevrenin, toplumun etkileri sonucu ortaya çıkan problemlerini çözebilmek için en isabetli en uygun kararları alabilecek yeterliği kazanmasına, yeteneklerini kavrayıp geliştirmesine, yeteneklerinin gerektirdiği, mümkün kıldığı öğrenim dalını ve ileride mesleği seçebilmesine çevresine uyabilmesine, böylece daha mesut bir toplum hayatının doğmasına, insan gücü kaynağının en isabetli şekilde değerlendirilmesine, yardım etmek rehberlik hizmetinin amaçlarından belli başlılarıdır.
\end{abstract}

Rehberlik hizmetlerinin gereği gibi yürütülebilmesi için okula alıştırma, öğrencileri tanıma, danışma ve yetiştirme, bilgi toplama ve yöneltme, izleme ve değerlendirme servislerinin gerekli olduğu belirtilmiştir.

\section{Millî Eğitim Şûrası (28 Eylül-3 Ekim 1970)}

8. ME Şûrası'nda, önceki iki yönetmelikle, yapısı belirlenmiş olan PDR hizmetlerinin içeriğinin netleştirilmesine yönelik çalışıldığı görülmektedir. Ortaöğretimin Kuruluşu ile Yükseköğretime Geçişin Yeniden Düzenlenmesi ana teması etrafında toplanan 8. ME şûrası, bu çerçevede okul PDR hizmetlerine geniş yer vermiş olan ilk şûra niteliğindedir. Türk Millî Eğitim Sisteminin Yapısı, Çeşitli Programlar, Yöneltme Sınıfı, Ortaöğretimde Yatay ve Dikey Geçişler, Yükseköğretime Geçiş başlıkları altında görüşülen konuların her biri kapsamında PDR hizmetleri de ayrıntılı bir biçimde ele alınmıştır.

Şûrada rehberlik hizmetlerinin tanımı konusunda alınan karar şu şekildedir:

1) “...okullarda iyi işleyen bir rehberlik düzeninden yararlanılmak suretiyle başarılarına göre öğrencileri ortak mecburi derslere ve seçmeli derslere yöneltmek" (Karar 40, s. 6).

2)“... rehberlik yolu ile istidat ve kabiliyetleri anlama, buna göre ya ikinci devrenin çeşitli programlarına yönelme ya da hayata hazırlama bakımından yardım edilmesi" (Karar 7/b, s. 2).

Not Verme Düzeni başlığı altında, “Öğrencileri başarılarına göre yöneltmek ve çalışmaya teşvik etmek esas olduğu" vurgulanmaktadır (Karar 42. s. 6).

Şûrada, ortaöğretimin ikinci kademesinin ilk yılının (9. sınıf), yöneltme sınıfı olarak belirlenmesi kararı alınmış (Karar 16, s. 3) ve izleyen maddelerde (Madde 17-21) yöneltme sınıfı açıklamalarına yer verilmiştir. Öğrencinin yöneltme sınıfından sonra yönelebileceği program konusunda, "rehberlik servisi"ne teklif bildirme görevi verilmiş (Karar 19, s. 3), ikinci devrenin çeşitli programlarına yöneltmenin "yol gösterici" nitelikte olması öngörülmüş (Karar 7/c, s. 2), lise düzeyinde "çeşitli programlar arasında yatay ve dikey geçiş yolları" açılması (Karar 13/d) şeklinde tavsiye kararları ortaya konulmuştur.

Bu kararlar, 8. ME Şûrası'nda herkesi "kabiliyetine göre yükseköğretim dalına, iş hayatına veya hem yükseköğretime hem de hayata hazırlanması" anlamında; (şûra açlış konuşması, s. 1) yani PDR hizmetlerinin, Türk Milli Eğitim Sisteminde yönlendirme amacıyla yer almasının önemi ve gereği üzerinde durulduğunu göstermektedir. Okullarda PDR hizmetlerini verecek örgütlenmenin, yöneltme ile eş anlamlı olarak kurulması kararlaştırılmıştır. 


\section{İkinci Beș Yıllık (1968-1972) Kalkınma Planı}

PDR alanına ilişkin 4 madde yer almaktadır (MEB Rehberlik ve Araştırma Merkezi Yönetmeliği, 1968):

1)“Gençlerin psikolojik sorunlarında yardım edici ve kabiliyetlerine uygun mesleğe yönelmeleriyle ilgili rehberlik hizmetleri yeterli bulunmamaktadır" cümlesinde kişisel ve mesleki gelişim için yardım gereği vurgulanmaktadır (Durum başlı̆ğ altında, s. 256).

2)“Gençlere ortaokul ve liselerde sosyal ve mesleki rehberlik hizmeti sağlanacaktır. Bu hizmet gençlerin özel problemlerinde, ders dışı faaliyetlerin geliştirilmesinde, kabiliyetlere göre daha üst seviyede öğrenime veya okulu bırakanların mesleğe yönelmelerinde, tatil aylarında bir işte çalışmalarını düzenlemede yardımcı olacaktır" (Uygulanacak Politikalar alt başlığı altında, s. 257).

3)“Okul çağındaki çocuklara sağlanacak sosyal hizmetlerde, rehber öğretmenler tarafından yapılacak yöneltme ve sosyal yardım faaliyetlerinde okul aile birlikleri ile rehberlik ve ruh sağlığı merkezlerinin desteğinden yararlanılacaktır. Bu okullarda iş eğitimi ağırlık taşıyacaktır." (Uygulanacak Politikalar: A. Organizasyon Yönünden başlığı altında, Madde 6, s. 232).

4) “Genç neslin sağlam olarak yetişmesi amacıyla okullarda sağlık hizmeti bir ihtisas dalı olan okul hekimliğinin geliştirilmesiyle sağlanacaktır. Gençlere sağllk yönünden yeterli bilgiler vermek için, okul içinde ve dışında gençlik gruplarına yönelmiş sağlık eğitimi çalışmaları yapılacaktır, özellikle genç yaşların ruhi sorunlarının çözülmesinde faydalı olan ruh sağlığı ve rehberlik hizmeti yaygın duruma getirilecektir" (Madde 6, s. 257).

Bu ifadelerde, gençlerin öncelikle sosyal ve mesleki gelişimlerinin amaçlandığı anlaşılmaktadır. PDR, bir sosyal yardım ve yöneltme hizmeti olarak görülmektedir. Gençlerin mesleki yönelmelerine yardım görevi üç madde de yer almaktadır. Ruh sağlığını geliştirme hizmetinin tüm maddelerde belirtilmiş olması dikkat çekmektedir. Gençlerin ruh sağlığı için okullarda PDR hizmetlerinin yanında okul hekimliği hizmetinin de verilmesi öngörülmektedir. Okul hekimliği ve öğrencilerinin "tatil aylarında bir işte çalışmalarını düzenleme" günümüzde birçok gelişmiş eğitim sisteminde yer almaktadır, ancak Türkiye'de henüz kurumsallaşamamıştır. Rehberlik ve ruh sağlığı, gençlerin psikolojik sorunlarında yardım, okul hekimliği, yöneltme, sosyal ve mesleki rehberlik, uygun mesleğe yönelmeleriyle ilgili rehberlik rehber öğretmen şeklinde kullanılmış olan PDR kavramları üzerinden, okul rehberlik hizmetleri ile gençlerin, kişisel ve sosyal yönleri gelişmiş olarak üretime kazandırmasının beklendiği görülmektedir (MEB Rehberlik ve Araştırma Merkezi Yönetmeliği, 1968). Birinci bulgu olarak elde edilen veriler Tablo 1'de özetlenmiştir.

Tablo 1

İkinci Beş Yıllık Kalkınma Planı, 1968 Yönetmeliği, 1970 Genelgesi ve 8. ME Şûra Kararlarında Okul PDR Hizmetlerine Bakış

\begin{tabular}{|c|c|}
\hline \multicolumn{2}{|c|}{ 1968-1972 İkinci Beş Yıllık Kalkınma Planı (21.8.1967) } \\
\hline PDR Tanımı & $\begin{array}{l}\text { Yöneltme ve sosyal yardım- sosyal ve mesleki rehberlik } \\
\text { Gençlerin özel problemlerinde, ders dışı faaliyetlerin geliştirilmesinde, kabiliyetlere yönelmelerinde, tatil } \\
\text { aylarında bir işte çalışmalarını düzenlemede yardım. }\end{array}$ \\
\hline Kavramları & Mesleki rehberlik/yöneltme (4 kez), ruh sağlığ1 (3 kez), rehberlik (2 kez), okul hekimliği, rehber öğretmen \\
\hline \multicolumn{2}{|c|}{ 1968-Rehberlik ve Araştırma Merkezi Yönetmeliği (12.02.1968) } \\
\hline PDR Tanımı & $\begin{array}{l}\text { Merkez: Özel eğitime muhtaç çocuklara rehberlik, mesleki rehberlik } \\
\text { Okul Grup Rehberliği Bölümü: Mesleki rehberlik, öğrencileri tanıma, başarı sağlayamayan öğrencilere yardım. }\end{array}$ \\
\hline Kavramları & $\begin{array}{l}\text { Okul ve meslek seçimi (5 kez), Başarısız öğrencilere yardım (4 kez), } \\
\text { Özel eğitime muhtaç öğrenciler -üstün zekâlı, engelli, uyumsuz (4 kez), öğrencileri tanıma, ruh sağlığı. }\end{array}$ \\
\hline \multicolumn{2}{|c|}{ 1970- Orta dereceli Okullarda Rehberlik Servislerinin Kuruluşu ve Görevleri ile İlgili Bazı Esaslar Genelgesi (10.06.1970) } \\
\hline PDR Tanımı & Öğrenciyi tanıma, kişisel, sosyal ve akademik problemlerini çözmelerine yardım, mesleki rehberlik. \\
\hline Kavramları & $\begin{array}{l}\text { Okul/mesleğe yöneltme ( } 4 \text { kez), öğrencileri tanıma ( } 2 \mathrm{kez}) \text {, problem çözme ( } 3 \mathrm{kez}) \text {, karar alma ( } 3 \mathrm{kez}) \text {, } \\
\text { Öğrencileri tanıma, } \\
\text { İnsan gücü kaynağının en isabetli şekilde değerlendirilmesi. }\end{array}$ \\
\hline \multicolumn{2}{|c|}{ 8. ME Şûrası (28 Eylül-3 Ekim 1970) } \\
\hline PDR Tanımı & $\begin{array}{l}\text { Öğrencileri tanımak, özelliklerine ve başarılarına göre derslere, çeşitli programlara yönlendirmek, hayata } \\
\text { hazırlamak. }\end{array}$ \\
\hline Kavramları & Derslere, çeşitli programlara yöneltmek (23 kez), rehberlik (5 kez) \\
\hline
\end{tabular}


Rehberlik ve Araştırma Merkezi Yönetmeliğinin (MEB Rehberlik ve Araştırma Merkezi Yönetmeliği, 1968) özel eğitim alanına hizmeti öne çıkaran yapısı ve öğrencileri tanıma servisinde doktor ve hemşire temsilcilerinin bulunmasına ilişkin ifade, 2. Beş Yıllık Kalkınma Planında, öncelikle psikolojik sağlık ve uygun mesleğe yöneltme konularının, okul PDR alanının en önemli görevleri olarak görülmesiyle uyumluluk göstermektedir. 1970 genelgesinde de kalkınma planına tümüyle bağlı bir tutumla çalışıldığı görülmektedir. Genelge metninde, öğrencileri tanıma, kişisel, sosyal ve akademik problemlerini çözme kararı alma yeterliği kazanmalarına yardım, okul seçimi, bir mesleğe yönelmelerinde rehberlik, insan gücü kaynağının en isabetli şekilde değerlendirilmesi gibi kalkınma planı ile aynı kavramlar kullanılmıştır. 8. ME Şûrası'nda ise PDR meslek alanının büyük ölçüde yöneltme amacı etrafında tanımlanmış olmasıyla, benzer bakış sergilediği görülmektedir. Alan çalışanları, kalkınma planındaki gibi "rehber öğretmen" olarak adlandırılmıştır. Sonuç olarak, 2. Beş Yıllık Kalkınma Döneminde gerçekleşen çalışmalarda okul PDR hizmetlerinin büyük ölçüde ortak bir bakışla tanımlandığı sonucu ortaya çıkmaktadır.

\section{Bulgu 2: 1985- Rehberlik Hizmetleri Yönetmeliği Çerçevesinde Okul PDR Hizmetlerine Bakış}

Rehberlik Hizmetleri Yönetmeliği (1985), 5. Beş Yıllık (1985-1989), kalkınma dönemi içinde yürürlüğe girmiş ve bu dönemde 18-22 Haziran 1988 tarihinde 12. ME Şûrası gerçekleştirilmiştir. Rehberlik Hizmetleri Yönetmeliği başlangıcında (Karar 3), “2916 sayılı Özel Eğitime Muhtaç Çocuklar Kanunu'nun (15.10.1983 tarih ve 18192 sayı) 6,7 ve 20. maddelerine göre hazırlanmıştır" ifadesinin yer alması, bu yönetmeliğin özel eğitime hizmet bakışıyla sorun odaklı rehberlik anlayışına dayandırıldığını düşündürmektedir. Yönetmelik metinde Genel Hükümler başlığı altında (Madde 6-8, s. 527-528), RAM görevi, “Milli Eğitim, Gençlik ve Spor müdürlüğüne bağlı olarak il merkezlerinde özel eğitim ve okul rehberlik hizmetlerini düzenlemek yürütmek, bu alanlarda araştırma yapmak ve özel eğitime muhtaç çocuklara hizmet götürmek üzere RAM başkanlığı kurulur" (Karar 6, s. 527) ifadesinde özel eğitim hizmetlerinin önceliği görülmektedir.

Yönetmelik metninin girişinde, okul PDR hizmetlerini tanımlama cümlesi kurulmamıştır. Dördüncü Bölüm/Okul Rehberlik Hizmetleri/ Okul Rehberlik Hizmetleri Kurulları başlı̆̆ı altında (Madde 24, s. 530) “Öğrencilerin kendilerini, okul içi ve okul dışı öğretim imkânlarını, meslekleri ve toplum değerlerini tanımalarına, yeteneklerine uygun bir öğretim programı seçmelerine, sağlıklı ve topluma faydalı bir kişi olarak yetişmelerine yardım etmek amacıyla çeşitli kurullar kurulur" cümlesinde, PDR hizmetleri için tanımlanmış olan, topluma sağlıklı ve üretken bireyler yetiştirme rolü öne çıkarılmıştır.

Hizmet alanı, rehberlik; alan çalışanı okul rehber öğretmeni olarak adlandırılmıştır. Yani psikolojik danışma kavramının kullanıma sokulmadığı görülmektedir. Okul rehber öğretmeni unvanı altındaki görevlere bakıldığında (Madde 32, s. 531) rehberlik programı (a, s, ş bendi), oryantasyon (b bendi), bilgilendirme (c bendi), sınıf içi rehberlik çalışmaları (d bendi) problemli ve rehberliğe muhtaç öğrencilerin saptanması (e bendi), mesleki rehberlik ( $f, g$, $h$ bendi), üstün yetenekli öğrenciler ( 1 bendi), psikolojik danışmanlık (i, j, k bendi), velilere müşavirlik (l bendi), rehberlik araçları geliştirme ( $\mathrm{m}$ bendi), çevre ilişkileri(o bendi) ve izleme ( $p$ bendi), disiplin kurulu üyeliği ( $r$ bendi) gibi çok sayıda görev sıralanmaktadır. PDR çalışmalarının ilkokuldan itibaren, rehberlik programına bağlanmış olması, kalkınma planıyla uyum göstermektedir.

Sonuç olarak bu yönetmeliğin, özel eğitime muhtaç çocuklara hizmeti öne alan yaklaşımında sorun odaklılık görülmekle birlikte, ilkokuldan itibaren belli bir programa dayalı rehberlik çalışmalarıyla, öğrencilerin kişisel-sosyal ve mesleki yönlerden gelişmiş bireyler olarak topluma kazandırılması anlayışı ortaya çıkmaktadır.

\section{On İkinci Millî Eğitim Şûrası}

Türk eğitim sistemini yeniden yapılandırmak amacı çerçevesinde 18-22 Haziran 1988 tarihinde toplanmış olan 12. ME Şûrası'nda, PDR hizmetlerine üç kararla yer verilmiştir:

1)“Bütün ortaöğretim kurumlarında öğrencilerin ilgi, istidat ve kabiliyetlerine göre yönlendirilmelerini ve karşılaştıkları problemlerin çözümünde yardımcı olacak ve böylece öğrencilerin daha başarılı olmalarını kolaylaştıracak bir ortamın sağlanması için rehberlik faaliyetlerinin etkinleştirilerek yaygınlaştırılması; bu 
çerçevede öğrencilerin beden ve ruh sağlıkları ile eğitim durumlarını takip edecek bir sistemin geliştirilmesi" (Genel, Mesleki ve Teknik Ortaöğretim başlığı altında, Karar 25, s. 5). Bu ifadede, yönlendirmenin ön planda belirtildiği görülmektedir. Öte yandan, öğrencilerin beden ve ruh sağlıkları ile eğitim durumlarını geliştirmeyi değil de, takip etmeyi öneren, sorun odaklı bakış dikkat çekmektedir.

2)“Rehberlik faaliyetlerinin; öğrencilerin kendilerini tanımalarına, sosyal ilişkilerinde olumlu bilgileri kazanmalarına ve öğrendikleri bilgileri davranış hâline getirmelerine imkân verecek şekilde yapılması" (7. Öğretim Programları - Karar 22, s. 15).

3)“Ülkemizin ekonomik ve sosyal şartlarına uygun olarak eğitim ve öğretimdeki millî hedeflere bir an önce ulaşmak amacıyla yapılacak çok yönlü planlamalara göre, öğrencilerimize okul öncesinden itibaren iyi bir rehberlik hizmetinin verilmesi" (C- başlığı altında, Karar 3, s. 6 ).

Bu ifadelerde, PDR hizmetlerinin, anaokulundan itibaren, çok yönlü planlamalarla, öğrencilerin beden ve ruh sağlıklarını, okul başarılarını, ilgi, istidat ve kabiliyetlerine göre yönlendirilmelerini sağlayan bir hizmet alanı olarak görüldüğü anlaşılmaktadır.

\section{Beşinci Beş Yıllık (1985-1989) Kalkınma Planı}

PDR alanına ilişkin aşağıdaki üç madde yer almaktadır:

1) “Ortaöğretimden başlanarak okula devam eden ve gençlere mesleğe yöneltme hizmetleri verilmesi sağlanacaktır" (Karar 480, s. 133).

2)“Illköğretim anasınıfını, ilkokulu ve ortaokulu kapsayan eğitim kademesidir, öğrenciyi tanıma, yöneltme, üst öğrenime ve mesleğe hazırlama; diğer eğitim basamaklarıyla ve çevreyle bütünleşme ilköğretimin temel özellikleridir" (Karar 539, s. 141).

3)“Ortaokullarda mesleğe yöneltme ve çevre şartlarına göre geçerli beceriler kazandırma uygulamasına başlanacaktır" (Karar 545, s. 142). Bu ifadelerde, PDR alanına, yöneltme anlayışıyla yaklaşıldı ğı görülmektedir. Okul PDR hizmetlerinin ilköğretimden itibaren, yönlendirme kapsamında, öğrenciyi tanıma, çevre şartlarına göre geçerli beceriler kazandırarak, üst öğrenime ve mesleğe hazırlama olarak tanımlandığı anlaşılmaktadır.

1985- Rehberlik Hizmetleri Yönetmeliği Çerçevesinde Okul PDR Hizmetlerine Bakışa ilişkin analiz bulguları Tablo 2' de özetlenmiştir.

Tablo 2

Beşinci Beş Yıllık Kalkınma Planı, 1985 Yönetmeliği ve 12. ME Şûra Kararlarında Okul PDR Hizmetlerine Bakış

\begin{tabular}{ll}
\hline Beşinci Beş Yıllık (1985-1989), Kalkınma Planı (13.07.1984) \\
\hline Tanım & Mesleğe yöneltme \\
Kavramlar & Yöneltme-üst öğrenime, mesleğe (4 kez), \\
& Çevre şartlarına göre geçerli beceriler kazandırma (2 kez) \\
& Öğrenciyi tanıma \\
\hline 1985- Rehberlik Hizmetleri Yönetmeliği (02.09.1985) \\
\hline Tanım & Özel eğitime muhtaç çocuklara rehberlik ve danışmanlık \\
& Kendini, eğitsel çevreyi, meslekleri, toplum değerlerini tanımalarına ve yeteneklerine uygun bir öğretim \\
& programı seçmelerine yardım \\
\hline Kavramlar & Rehberlik programı (4 kez), Mesleki rehberlik (3 kez), Psikolojik danışmanlık (3 kez) \\
\hline 12. ME şûrası & (18-22 Haziran 1988) \\
\hline Tanım & Yönlendirme, problem çözümü, başarı, beden, ruh ve sosyal gelişim, kendini tanıma hizmetleri \\
Kavramlar & Yönlendirme, problem çözüm, başarı, beden ve ruh sağlığı, kendini tanıma, sosyal gelişim \\
\hline
\end{tabular}

1985 Yönetmeliğinin, özel eğitime muhtaç çocuklara hizmeti öne alan yaklaşımında sorun odaklılık görülmekle birlikte, ilkokuldan itibaren, belli bir programa dayalı rehberlik çalışmalarıyla, öğrencilerin, kişisel-sosyal ve mesleki yönlerden gelişmiş bireyler olarak topluma kazandırılması anlayışı, kalkınma planı kararlarına uygun düşmektedir. Kalkınma planında, okul PDR hizmetlerinin amacı, ilköğretimden itibaren, üst öğrenime ve mesleğe yönlendirme amaçlı olarak, öğrenciyi tanıma, çevre şartlarına göre geçerli beceriler kazandırma olarak tanımlanmıştır. Yönetmelik, kalkınma planındaki gibi, yöneltmeye yer verirken öğrencilerin toplum değerlerini tanımalarına yardım amacını da eklemiş görünmektedir. 12. ME şûra 
kararlarında da, PDR hizmetlerinin yöneltme işlevi vurgulanmıştır: “...anaokulundan itibaren, çok yönlü planlamalarla, öğrencilerin beden ve ruh sağlıklarını, okul başarılarını, ilgi, istidat ve kabiliyetlerine göre yönlendirilmelerini sağlayan bir hizmet alanı". Ayrıca, ülkenin ekonomik ve sosyal şartlarına uygun insan yetiştirme, yani "toplum için birey" ifadesinde de kalkınma planı ve yönetmelikle uyum görülmektedir. Yönetmelikte, bir hizmet grubu olarak yer almaya başlamış olan psikolojik danışma kavramına şûrada sahip çıkılmamış olması dikkat çekmektedir. Rehberlik programı ve psikolojik danışma kavramları, sadece yönetmelikte yer almaktadır. ME şurasında alan hizmetlerini rehberlikle sınırlı gören bakış hâkimdir. Sonuç olarak, 1985 yönetmeliğinin daha çok özel eğitime odaklı oluşuyla kalkınma planının, ME Şûrası'nın ise psikolojik danışma kavramına kapalı oluşuyla, yönetmeliğin gerisinde kaldığı söylenebilir.

\section{Bulgu 3: 2001 MEB PDR Hizmetleri Yönetmeliği Çerçevesinde Okul PDR Hizmetlerine Bakış}

MEB PDR Hizmetleri Yönetmeliği (2001) ve 2003 İlköğretimde Yöneltme Yönergesi, Sekizinci Beş yılllk Kalkınma döneminde yürürlüğe girmiştir. Yönetmelikte, okul PDR hizmetleri tanımının, "kendini gerçekleştirme" kavramı etrafında yapılandırıldığı görülmektedir. "Türk Eğitim Sisteminin genel amaçlan çerçevesinde eğitimde rehberlik ve psikolojik danışma hizmetleri temelde; öğrencilerin kendilerini gerçekleştirmelerine, eğitim sürecinden yetenek ve özelliklerine göre en üst düzeyde yararlanmalarına ve gizilgüçlerini en uygun şekilde kullanmalarına ve geliştirmelerine yöneliktir" (Rehberlik ve Psikolojik Danışma Hizmetlerinin Amacı alt başlığı altında, Madde 6).

PDR hizmetlerinin amacını tanımlayan maddenin altında, kapsamlı biçimde eğitsel (Madde 7), mesleki (Madde 8) ve bireysel (Madde 9), rehberlik tanımları yapılmıştır. “Öğrencilerin sorunlarına yardımın yanı sıra, onların kişilik ve sosyal gelişimlerine ve olgunlaşmalarına destek olmayı" amaçlayan bireysel ve grup etkinlikleri bireysel rehberlik olarak adlandırılmış (Madde 9/f) ve izleyen maddelerde Bireyi Tanıma (Madde 10) ve Grup Rehberliği Etkinlikleri (Madde 11) tanımlanmıştır. Buradaki "Bireysel rehberlik" kavramı, 2017 yönetmeliğinde "Kişisel-sosyal rehberlik" şeklinde düzeltilecektir.

Öğretim kademelerine göre PDR hizmetleri tanımlamalarında (Madde 12) okul öncesi ve ilköğretimin birlikte ele alınmış olması dikkat çekmektedir. PDR Hizmetlerinin, “öğrenci özelliklerinin, kendisi, öğretmeni/öğretmenleri ve ailesi tarafından fark edilmesine, öğrencinin yetiştiği ortamın iyileştirilmesine, bireysel eğitsel ve sosyal gelişimlerinin desteklenmesine, ilköğretim sonrası eğitime devam edemeyecekler için mesleğe yönlendirmeye yönelik çalışmalar" olduğu belirtilmektedir. Orta öğretimde hizmetlerin, öncelikle yöneltme amacına yoğunlaştığı görülmektedir. Eğitsel, bireysel ve sosyal gelişimin sürdürülüp yetişkin yaşamına hazırlanmasına yardım hizmetleri de belirtilmektedir. 12. maddeye eklenen “... Yaygın eğitimdeki rehberlik ve psikolojik danışma hizmetleri genelde kursiyerlerin mesleğe ve işe yönlendirilmesini, iş yaşamına hazırlığı, bireysel ve sosyal gelişimlerinin desteklenmesini kapsar" ifadesiyle ilk kez yaygın eğitimde PDR hizmetlerinden söz edilmiştir. Bu ifadelerde, okul öncesi ve ilköğretimde öncelikle kendini gerçekleştirmenin, ortaöğretimde ise mesleki yönlendirme açısından kendini gerçekleştirmenin önemli olduğu belirtilmektedir. Yönlendirme hizmetlerinin, "Rehberlik ve psikolojik danışmada yönlendirme" şeklinde değil de "Yönlendirmedeki rehberlik ve psikolojik danışma" olarak ve ayrı bir başlık altında ifade edilmesi dikkat çekmektedir. Yöneltme kavramı, "yöneltmedeki/yönlendirmedeki rehberlik ve psikolojik danışma hizmetleri" ifade şekliyle (Madde 4, 13, 18/i, 23-k, 36/d) geçmektedir. "Eğitsel, meslekî, bireysel rehberlik ile bireyi tanıma uygulamalarının ve sonuçlarının öğrencinin yönlendirilmesi için ... bütünleştirilmesi esastır" (Madde 13) cümlesinde de yönlendirmenin öne çıkarıldığı görülmektedir. "Bilgisayar destekli rehberlik" kavramı iki maddede (Madde 28/ö, 35) yer almaktadır. Mesleki danışmanlık ve kariyer danışmanlığı kavramlarının hiç kullanılmadığı, mesleki rehberlik kavramının tercih edildiği (Madde 8/a-d, 10, 11, 13 ,15, 30-b, 46/d, 50/c, e, g, 51/b) görülmektedir.

2001 yönetmeliği, PDR çevreleri tarafından öncekine göre daha çağdaş nitelikte görülmüştür. Önceki yönetmelikte "Rehberlik Hizmetleri" olarak belirlenmiş olan yönetmelik ismine "Psikolojik Danışma" ifadesi eklenmiştir. Okulda PDR hizmeti veren elemanların önceki yönetmelikte "Rehber Öğretmen" olarak belirlenmiş olan unvanı da bu yönetmelikte "Psikolojik Danışman" (Madde 49, 50) olarak değiştirilmiştir. Bununla birlikte, Devlet Personel Yasasında "psikolojik danışman" kadrosunun yer almaması nedeniyle 
unvan ve rol çatışması sorununun çözüme ulaştırılamamıştır.

İlköğretimde Yöneltme Yönergesi'nin (2003) amacı MEB'e bağlı ilköğretim okulları öğrencilerinin ilgi, istek, yetenek ve kişilik özelliklerini dikkate alarak; olumlu bir benlik kavramı geliştirebilmelerine, seçeneklerden haberdar olmalarına, potansiyellerinin farkında olarak onu geliştirmeye çalışmalarına, bu doğrultuda kararlar alabilmelerine, aldıkları kararların sonuçlarını görebilmelerine ve sorumluluğunu almalarına yönelik bilimsel hizmetlerin düzenli ve sürekli bir biçimde verilmesi (Madde $4 \mathrm{~b}$ ) ve bireyin kendini tanıması ve kabul etmesi, problemlerini çözmesi, gerçekçi kararlar alması, kapasitesini geliştirmesi, çevresine dengeli ve sağlıklı biçimde uyum sağlaması ve böylece kendini gerçekleştirebilmesi için uzman kişilerce bireye verilen sistematik ve profesyonel yardım süreci (Madde 4a), vurgulanarak okul PDR hizmetleri tanımının, 2001 yönetmeliğine uygun bir şekilde, "kendini gerçekleştirme” kavramı etrafında yapılandırıldığı görülmektedir.

PDR alanı, yönetmelikle uyum içinde, Rehberlik ve Psikolojik Danışmanlık olarak adlandırılmıştır. Buna karşın alan çalışanının unvanı konusunda, yönetmelikten farklı ve geriye doğru bir yönelimle rehber öğretmen tanımlaması kullanılmıştır. Yönlendirmeyle ilgili mesleki rehberlik, kariyer danışmanlığı, bilgisayar destekli rehberlik kavramlarının hiçbirinin kullanılmamış olması da geri bir yönelim olarak nitelenebilir.

\section{Sekizinci Beş Yıllık (2001-2005) Kalkınma Planı}

Plan metninde, okul PDR hizmetleriyle ilgili kavramların geçtiği toplam yedi madde yer almaktadır. "Milli eğitim, herkes için hayat boyu öğrenme yaklaşımılla bilgiye ulaşma yol ve yöntemlerini öğreten, etkin bir rehberlik hizmetini içeren, eğitimin tüm evrelerinde yatay ve dikey geçişlere imkân veren, piyasa meslek standartlarına uygun, üretime dönük eğitime ağırlık veren, yetki devrini esas alan, istisnasız tüm öğrenciler için fırsat eşitliğini gözeten bir sistem bütünlüğü içerisinde yeniden düzenlenecektir" (Madde 676, s. 81). Bu ifade de okul rehberlik hizmetlerinin, yönlendirme dişında, "bilgiye ulaşma yol ve yöntemlerini öğretmeye yönelik eğitsel rehberlik" ile genişletildiği görülmektedir.

PDR hizmetlerinin, "piyasa meslek standartlarına uygun, üretime dönük eğitime ağırlık veren" bir sistem içinde yer alması gereği belirtilmekte ve "Eğitim sisteminin geliştirilmesi, ekonominin nitelikli işgücü ihtiyacını karşılayacak ve uluslararası rekabet gücünü artıracak şekilde sürdürülecektir" denilmektedir (Madde 42, s. 223). Yine yönlendirme amacıyla ilişkili olarak, 680. maddede, ilköğretimin ikinci aşamasından itibaren bilgisayar destekli yönlendirme hizmetlerinin geliştirilmesinin önemi belirtilmektedir: "İlköğretimin ilerleyen sınıflarından başlamak üzere, eğitimin her kademesinde Bilgisayar Destekli Rehberlik yoluyla öğrenciyi tanıma teknikleri ve yetenek ağırlıklı değerlendirmeye dayanan etkin bir yönlendirme sistemi geliştirilecektir (s. 83).

“Üstün zekâlı ve üstün yetenekli çocukların rehberlik ve danışmanlık yardımını okul öncesi ve ilköğretim çağında almasına ve bu çocuklar için uygun eğitim ortamlarının hazırlanmasına ağırlık verilecek ve özel sektörün bu alandaki girişimleri desteklenecektir" (İnsan Kaynaklarının Geliştirilmesi/ Eğitim başlığı altında Madde 689, s. 84).

Ortaöğretimin, "okul türü yerine program türünü esas alan bir yapıya kavuşturulacağ1" (Madde 690), "Yükseköğretime giriş sisteminin, öğrencilerin ilgi ve yeteneklerine uygun programlara yerleştirilmesini sağlayacak şekilde yeniden düzenleneceği" (Madde 695) şeklindeki ifadelerde de etkin bir yönlendirme sistemi geliştirme iradesi sergilenmektedir. Bu ifadeler, eğitimde yönlendirmeye verilen önemi ortaya koymaktadır. Yöneltme yanında yeni bir bakışla, eğitsel rehberlik de eklenmiştir.

"Kariyer danışmanlığı sistemi, mesleki danışmanlık sistemi" kavramlarıyla belirtilen ifadelerde, mesleğe yönlendirme çalışmalarının örgün eğitim dışında da önemli görüldügü anlaşılmaktadır. Sosyal ve Ekonomik Sektörlerle İlgili Gelişme Hedef ve Politikalar başlığı altında işsizlere yönelik kariyer danışmanlığından (Madde 603, s. 75; Madde 928, s. 102), Türk meslekler sözlüğünün güncelleştirilmesi ve iş gücü enformasyon sisteminin geliştirilmesi çalışmalarından (Madde 929, s. 102) söz edilmektedir:

8. Beş Yıllık Kalkınma Planı, 2001-PDR Hizmetleri Yönetmeliği ve 2003-İlköğretimde Yöneltme Yönergesinde ortaya çıkan tanımlama ve kavramlar Tablo 3'te sunulmuştur. 
Tablo 3

Sekizinci Beş Yıllık Kalkınma Planı, 2001 Yönetmeliği ve İlköğretimde Yöneltme Yönergesi Kararlarında Okul PDR Hizmetlerine Bakış

\begin{tabular}{ll}
\hline Sekizinci Beş Yıllık (2001-2005), Kalkınma Planı \\
\hline Tanım & $\begin{array}{l}\text { Hayat boyu bilgi edinme yöntemlerini öğretmeye, öğrenciyi tanımaya ve yetenek değerlendirmeye yönelik } \\
\text { bilgisayar destekli rehberlik } \\
\text { Kehberlik hizmeti (2 kez), Rehberlik ve danışmanlık, Mesleki Danışmanlık Sistemi (2 kez), Yönlendirme sistemi } \\
\text { (5 kez), Kariyer danışmanlığı, Bilgisayar Destekli Rehberlik (2 kez) }\end{array}$ \\
\hline 2001 MEB PDR Hizmetleri Yönetmeliği \\
\hline Tanım & Kendini gerçekleştirme- Üst öğrenime, meslek alanlarına ve mesleğe yöneltme \\
Kavramlar & Psikolojik danışma/danışmanlık (100 den fazla), Psikolojik danı̧man (33 kez) \\
& Mesleki rehberlik (12 kez), Eğitsel ve mesleki rehberlik (7 kez) \\
\hline Yöneltme (4) rehberlik (2 kez), Bilgisayar destekli rehberlik (2 kez)
\end{tabular}

Tablo 3 üzerinde şu noktalar dikkat çekmektedir:

- Yönetmelik, yönerge ve kalkınma planında yöneltme amacı konusunda ortak bir anlayış ortaya çıkmaktadır.

- Sekizinci kalkınma planında, PDR alanına özgü danışmanlık, kariyer danışmanlığı, Bilgisayar Destekli Rehberlik gibi yeni kavramların kullanılmış olması dikkat çekmektedir.

- Planla uyumlu olarak, yönetmelikte Bilgisayar Destekli Rehberlik kavramı kullanılmıştır. Buna karşın, kalkınma planında kullanılan mesleki danışmanlık kavramı konusunda bir devamlılık gösterilmediği, mesleki rehberlik olarak sürdürüldüğü görülmektedir. Aynı şekilde kalkınma planında ilk kez gündeme sokulan kariyer danışmanlığı kavramına da hiç yer verilmemiştir.

- Yöneltme yönergesinde PDR alan çalışanı konusunda, yönetmelikteki psikolojik danışman tanımlaması benimsenmemiş, rehber öğretmen kavramından vazgeçilmemiştir.

- Kalkınma planı ve yönetmelikte gündeme sokulmuş olan ve mesleki yönlendirme ile ilişkili mesleki danışmanlık, kariyer danışmanlığı ve Bilgisayar Destekli Rehberlik gibi diğer kavramlar, yöneltme yönergesinde yer almamaktadır.

Sonuç olarak, 2001 yönergesinin kalkınma planı ile alanı yeni kavramlarla tanımlama açısından uyumlu olduğu, 2003 yöneltme yönergesinin ise danışmanlık ve psikolojik danışman kavramlarına sahip çıkmadığı görülmektedir.

\section{Bulgu 4: 2017-MEB Rehberlik Hizmetleri Yönetmeliği Çerçevesinde Okul PDR Hizmetlerine Bakış}

Onuncu Beş Yıllık Kalkınma döneminde, 2017-MEB Rehberlik Hizmetleri Yönetmeliği 10 Kasım 2017 tarih ve 30236 sayılı Resmî Gazete ile yürürlüğe girmiştir. 2001 yönetmeliğinin üzerinden 16 yıl geçtikten sonra, ortaya çıkan değişikliklere uyum sağlamak için düzenlenen bu yönetmelikte PDR hizmetleri "rehberlik" kavramı etrafında aşağıdaki gibi tanımlanmıştır:

Rehberlik hizmetlerinin amaçları Madde 4 -(1) "Türk Millî Eğitiminin genel amaçları çerçevesinde eğitimde rehberlik hizmetleri; kendini tanıyan, kendisine sunulan eğitsel ve mesleki fırsatları değerlendirebilen, sorumluluk alabilen bireyler yetiştirilmesini ve bireylerin toplum içinde sağlıklı bir birey olarak yaşamlarını sürdürerek kendini gerçekleştirmelerini amaçlar" şeklinde düzenlenmiştir.

Rehberlik hizmetlerinin; bireyi tanıma (Madde 9) psikolojik ölçme araçlarının uygulanması (Madde 10), yönlendirme ve yerleştirme (Madde 11), psiko-sosyal koruma, önleme ve krize müdahale (Madde 12), danışmanlık tedbiri uygulamaları (Madde 13), aile rehberliği (Madde 14), öğretim kademelerine göre rehberlik (Madde 8/a, b, c, ç bendi) olarak, eğitsel, mesleki ve kişisel/sosyal rehberlik kapsamında üç alt boyutta yürütüldüğü belirtilmektedir. Okul öncesi dönemde rehberlik hizmetleri ile; çocuğun sosyal beceriler kazanması, olumlu benlik algısı ile mesleklere ilişkin olumlu tutumlar geliştirmesi ve aile rehberliği (a bendi) vurgulanmıştır. İlkokulda, öğrencinin eğitsel uyumu ve başarısı, kişilik ve mesleki gelişim (b bendi) 
önceliklendirilmiştir. Ortaokulda ise gelişim dönemi içinde öğrencinin kendini tanıması ve kişilik özellikleri doğrultusunda yönelmesi (c bendi) amaçlanmaktadır. Ortaöğretim kademesinde rehberlik hizmetlerinin, sosyal değerler kazandırma yönünde çalışmalar yapması (ç bendi) üzerinde ayrıca durulmaktadır.

Öğretim kademelerine göre rehberlik hizmetlerini tanımlayan ifadelerin, 2001 yönetmeliğindekilere büyük ölçüde benzediği dikkat çekmektedir. Bu yönetmelikte, okul öncesi ve ilköğretim kademesi ayrı ele alınmış ve öğretim kademeleri alt madde işaretleriyle (a, b, c şeklinde) ayrılmıştır. Öte yandan önceki yönetmelikte ilk kez değinilmiş olan "yaygın eğitimde rehberlik hizmetleri" konusunda da ayrı bir alt maddede (d bendi) daha ayrıntılı bir açıklama yapıldığı görülmektedir. Hayat boyu öğrenmeyi destekleyen, eğitsel, mesleki ve kişisel/sosyal rehberlik hizmetleri verilmesi gereği belirtilmektedir.

Alanlarına göre rehberlik hizmetleri tanımlamalarında, eğitsel rehberliğin, önceki yönetmeliğe göre daha kısa bir ifadeyle tanımlanmış olması, buna karşılık, mesleki rehberliğin, kariyer, hayat boyu öğrenme sürecinde kendini geliştirmesi için birey ve ailesine sunulan hizmet şeklinde kariyer gelişimine dönük geniş kapsamda ele alınmış olması (Madde 6/b) dikkat çekmektedir. Ayrıca, 2001 yönetmeliğinde, "bireysel rehberlik" olarak adlandırılmış olan hizmetlerin, burada "Kişisel/Sosyal rehberlik" şeklinde, ahlaki ve davranışsal gelişim, sosyal beceriler ile yaşam becerileri ve sorumluluk geliştirme kapsamında yine daha geniş bakışla tanımlanmış olduğu görülmektedir. Öte yandan, "Birey sayısına göre rehberlik hizmetleri" başlı̆̆1 altında (Madde 7), bireysel rehberliğin anlamı, "bireyin eğitsel, mesleki ve kişisel/sosyal gelişimine yönelik birebir sunulan rehberlik hizmeti" şeklinde 2001 yönetmeliğindeki anlamından farklı biçimde tanımlanarak düzeltilmiştir.

Alan adından psikolojik danışmanlık, alan çalışanı unvanı olarak psikolojik danışman kavramları ortadan kaldırılmış ve rehberlik hizmetleri, kullanılmış olduğu görülmektedir. Buna karşın, psikolojik danışma

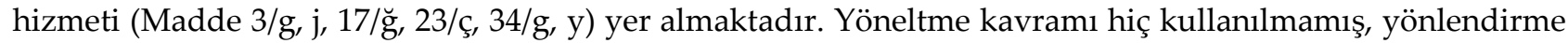
ve yerleştirme (Madde 11-1, 2, 23/e, 24/d, 30/ç, 35/d) mesleki rehberlik (Madde 6/b, 30/ç), Kişisel/Sosyal rehberlik (Madde 6/c, 8/a, b, c, ç, d, 11-1, 34-ç), eğitsel rehberlik (Madde 6/a), aile rehberliği (Madde 8-1, 14-1,2,

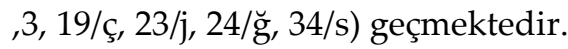

Bu özellikleriyle, 2017 yönetmeliğinin PDR tanımını önceki yönetmelikteki gibi "kendini geçekleştirme" çerçevesinde yapmayı sürdürdüğü, ancak "Psikolojik Danışma" konusundaki gelişime sahip çıkmadığ1 görülmektedir. Önceki yönetmelikte eklenmiş olan "Psikolojik Danışma" ifadesi kaldırılmış, yeniden yalnızca "Rehberlik Hizmetleri Yönetmeliği" olarak adlandırılmıştır. Yönetmeliğin adından itibaren yönetmelikte geçen tüm "PDR" tanımlamasından "Psikolojik Danışma" kavramı çıkarılmıştır. PDR servisi, "Rehberlik Servisi" olarak tanımlanmıştır (Karar 3/o). Burada, MEB'in PDR hizmetlerinin amacını, 32 yıl önceki, 1985 yönetmeliğinde olduğu gibi, yeniden psikolojik danışmanlıktan ayırarak rehberlik hizmetine indirgeyen bir geri dönüş yaklaşımı sergilediği görülmektedir.

Onuncu (2014-2018) Kalkınma Planı'nda (T.C. Kalkınma Bakanlığı, 2013) öncekilerde olduğu gibi, yönlendirme amacının öne çıkarıldığı görülmektedir: Ortaöğretim ve yükseköğretime geçiş sistemi, öğrencilerin ilgi ve yeteneklerini dikkate alan etkin rehberlik ve yönlendirme hizmetleri desteğiyle, süreç odaklı bir değerlendirme yapısına kavuşturulacaktır (Madde 150, s. 32). “Ortaokul ve liselerde bireysel yeteneklere göre öğrencileri yönlendirebilecek bir rehberlik sisteminin hayata geçirilmesi" (Eğitim Çağındaki Gençlerin Temel Becerilerinin Geliştirilmesi başlığı altında, s. 187) ve "Mesleki rehberlik ve danışmanlık hizmetleri başta olmak üzere aktif işgücü politikaları etki analizlerine dayandırılarak yaygınlaştırılması" amaçlanmaktadır (Madde 317, s. 47).

Kariyer sözcüğü geçmesine karşın, yalnızca aşağıdaki madde örgün eğitimle ilişkilidir:

“...kariyer gelişim ve performans değerlendirme sisteminin oluşturulması, izleme ve değerlendirme faaliyetlerinde etkinlik sağlanması, eğitim ile istihdam ilişkisinin güçlendirilmesine yönelik mekanizmaların etkinliğinin artırılması ihtiyacı devam etmektedir" (Madde 141, s. 31). Bunun dışında, PDR alanıyla ilgili, ancak örgün eğitim sonrası verilecek, başarılı sporcu yetiştirmek amacıyla yönlendirme (Madde 342, s. 49), İş ve İşçi Bulma Kurumu (İ̧̧KUR) bünyesinde, iş ve meslek danışmanlığı (s. 164, 187) gibi çalışmalar 
önerilmektedir. Özellikle tek ebeveynli ailelerin sorunlarının çözümüne yönelik ailelere yönelik izleme, rehberlik, uzlaştırma (Madde 248, s. 40, Madde 254, s. 41), ailelere danışmanlık (Madde 245, 250, s. 40), evlilik öncesi eğitim ve aile danışmanlık (Madde 122, s. 191) hizmetlerine de örgün eğitim dışında yer verilmesi üzerinde durulmuştur.

10. Kalkınma Planı'nda, örgün eğitimde PDR hizmetlerini yeniden tümüyle yönlendirme amacına yönelik geniş kapsamlı kararlar alınmıştır. Başarılı sporcu yetiştirmek iş ve meslek danışmanlığı evlilik ve aile danışmanlığı gibi yeni hizmetleri örgün eğitim dışında düzenleyen kararlar dikkat çekmektedir. Bu bölümün analiz sonuçları Tablo 4'te özetlenmiştir.

Tablo 4

Onuncu Beş Yıllık Kalkınma Planı ve 2017 Yönetmeliŭi Kararlarında Okul PDR Hizmetlerine Bakış

\begin{tabular}{ll}
\hline Onuncu Beş Yıllık (2014-2018) Kalkınma Planı (02.07.2013) \\
\hline $\begin{array}{l}\text { Tanım } \\
\text { Kavramlar }\end{array}$ & $\begin{array}{l}\text { Öğrencileri ilgi ve yeteneklerine göre yönlendirme (2 kez), Mesleki rehberlik ve danışmanlık } \\
\text { Rehberlik ve yönlendirme, Mesleki rehberlik ve danışmanlık }\end{array}$ \\
& Örgün eğitim dışında: İş ve meslek danı̧manları (2 kez), ailelere yönelik danışmanlık hizmetleri (7 kez) \\
\hline 2017 -MEB Rehberlik Hizmetleri Yönetmeliği (10.11. 2017) \\
\hline $\begin{array}{l}\text { Tanım } \\
\text { Kavramlar }\end{array}$ & $\begin{array}{l}\text { Kendini gerçekleştirmeye yardım hizmeti } \\
\text { Rehberlik hizmetleri (116 kez), Aile rehberliği (15 kez), Yönlendirme ve yerleştirme (8 kez), Kişisel/Sosyal rehberlik } \\
\text { (8 kez), psikolojik danışma (6 kez), mesleki rehberlik (2 kez), eğitsel rehberlik (1 kez) }\end{array}$ \\
\hline
\end{tabular}

2017 yönetmeliği, rehberlik hizmetleri tanımlamalarında mesleki gelişim ve yönelme bakışına yer vermesi açısından kalkınma planıyla uyumlu görünmektedir. Onuncu Kalkınma Planı'nda da öncekilerde olduğu gibi, tüm ifadelerinde okul PDR hizmetlerini yönlendirme amacına bağlayan bakış sergilenmektedir. İş ve meslek danışmanlığı, aile danışmanlığı gibi yeni hizmetler de gündeme getirilmiş; ancak bunlar örgün eğitim dışında verilecek hizmetler olarak önerilmiştir. 2017 yönetmeliği, okul PDR hizmetlerini danışmanlıktan ayırmış ve rehberlik düzeyinde tanımlamış olması yönünden hem kalkınma planının hem de önceki yönetmeliğin gerisinde bir yönelim ortaya koymaktadır.

\section{Tartışma ve Sonuç}

Bu çalışmada, Milli Eğitim Bakanlığı́'nın okul PDR hizmetlerine ilişkin düzenlemelerinde ortaya koyduğu PDR hizmetlerine bakışının, ME şûraları ve kalkınma planları kararlarında ortaya çıkan yaklaşımlarla uyumu sorgulanmıştır. Çalışmanın analiz sonuçlarına göre, İkinci Beş Yıllık Kalkınma Planı döneminde gerçekleşen 1968 Yönetmeliği, 1970 Genelgesi düzenlemeleri ve 8. ME şûrası kararlarında, okul PDR hizmetlerinin büyük ölçüde ortak bir bakışla tanımlandığı görülmektedir. Yönlendirme amacına verdikleri önem açısından uyumluluk gözlenmektedir. 1985 Yönetmeliği, kalkınma planı kararlarından daha çok, özel eğitim yönetmeliğine dayandırılmıştır. Bununla birlikte, okul PDR hizmetlerinin yöneltme işlevi de kalkınma planındaki gibi vurgulanmaktadır. Ayrıca, yönetmelikte "öğrencilerin toplum değerlerini tanımalarına yardım", 12. ME şûrası kararlarında ise "ülkenin sosyal şartlarına uygun insan yetiştirme" ifadelerinde ortaya çıkan toplumcu motif, PDR işlevlerine eklenmiş görünmektedir. 1985 yönetmeliğinde, rehberlik programı ve psikolojik danışma gibi yeni kavramlara yer verildiği görülmektedir. Ancak 12. ME şurasında psikolojik danışma kavramına sahip çıkılmamış, alan hizmetlerini rehberlikle sınırlı gören bakış sergilenmiştir. Okul PDR hizmetleri tanımını, "kendini gerçekleştirme" kavramı etrafında yapılandıran 2001 yönetmeliğinin, önceki yönetmeliğe göre daha yenilikçi bir yaklaşımla yazılmış olduğu dikkat çekmektedir. Yöneltme amacı konusunda, kalkınma planıyla ortak anlayış sürmektedir. 8. Kalkınma Planı'nın, danışmanlık, kariyer danışmanlığı, bilgisayar destekli rehberlik gibi yeni yaklaşımları ortaya koyan kararlarıyla uyumlu görünmektedir. Psikolojik danışma/ Psikolojik danışmanlık/ Psikolojik danışman kavramları vurgulu biçimde kullanılmıştır. Ancak, kalkınma planında mesleki danışmanlık yerine, daha sınırlı bir anlama sahip mesleki rehberlik kavramı tercih edilmiştir. 2003 Yöneltme Yönergesinde ise danışmanlık ve psikolojik danışman kavramlarına hiç yer verilmemiştir. Yönergeler, yönetmeliklerde değinilmeyen konulara açıklık getirmek için düzenlenen resmî belge niteliğinde olsalar da 2003 Yöneltme Yönergesinin, eğitsel ve mesleki yönlendirme konusundaki düzenlemeyi, rehberlik bakışıyla sınırlamayıp 8. Kalkınma Planı ve 2001 yönetmeliğiyle uyumlu biçimde, eğitsel ve mesleki danışmanlığı da içeren bir yaklaşımla ele alması beklenirdi. 2017 yönetmeliği, okul PDR hizmetleri tanımında, önceki yönetmeliğin "kendini geçekleştirme" kavramını sürdürmekle birlikte, 
"danışmanlık" kavramı konusunda, tümüyle 1985 yönetmeliğine geri dönüş yapmış olması açısından, 10. Kalkınma Planı kararlarında görülen yenilikçi bakışla uyumsuz görünmektedir.

Bu sonuçlar, MEB'in okul PDR hizmetlerine yönelik gerçekleştirdiği yönetmeliklerde ve şuralarda, kendi bakanlığının mevcut ve önceki planlama ve düzenleme çalışmalarıyla kavram birliğini gözeten ve geliştiren bir tutum izlemediği görülmektedir. Buna karşın, kalkınma planları ile her zaman uyum içinde PDR'nin yöneltme amacına yer verdiğini göstermektedir. Kalkınma planları, PDR alanını, yalnızca insan gücünü ülkenin ihtiyaç duyduğu alanlara yöneltme plânlaması hizmetlerinden ibaret saydığı ve bu bağlamda öğrenciyi birey olarak değil de, daha çok ekonomik bir varlık olarak ele aldığı için eleştirilmiştir (Doğan, 1991; Tan,1986). Yöneltme amacı açısından, en yüksek uyum, 1968 Yönetmeliği, 1970 Genelgesi ve 8. ME Şûrası ile 2. Beş Yıllık Kalkınma Planı arasında görülmektedir. Sonraki dönemlerde, PDR yönetmeliklerinde, kalkınma planlarının bu ekonomik nitelikli yöneltme bakışına bağlı kalınırken, kalkınma planlarının yöneltme amacı etrafında yeni açılımlar öneren sürekli ilerlemeci tutumunun gerisinde kalındığı gözlenmektedir. Örneğin, 2001 Yönetmeliği, rehberlik anlayışı sınırları içinde kalarak, 8. Kalkınma Planı'nın gündeme getirdiği mesleki danışmanlık, kariyer danışmanlığı gibi yeni yaklaşımları sahiplenmemiş görünmektedir. Mesleki danışmanlık yerine mesleki rehberlikle sınırlı kavramlar kullanılmıştır. 1985 yönetmeliği, daha çok özel eğitime odaklı oluşuyla; 2017 yönetmeliği ise alanı yeniden tümüyle rehberlik sınırlarına kapatan tutumuyla, kalkınma planı kararlarında sergilenen anlayışla uyumsuzdur. Halmatov'un (2014) çalışması, bu bulguları desteklemektedir. PDR hizmetlerinin gelişimine yönelik olarak kalkınma planları ve eğitim şûralarının birçoğunda önemli kararlar alınmasına karşın bu kararların önemli bir kısmının PDR hizmet alanında hayata geçirilmediği belirtilmektedir.

Asıl uyumsuzluk, yönetmelikler arasında gözlenmektedir. 1985 yönetmeliğinin, 1968-70 yıllarında yapılan düzenlemeleri dikkate alarak, daha ileri açılımlar ortaya çıkardığını söylemek zordur. 2001 yönetmeliğinde, beklenen yeniliklere açık bir düzenleme yapıldı̆̆ı; ancak 2017 yönetmeliğinde bu kazanımları sürdürmek ve geliştirmek yerine 1985 yönetmeliğine geri dönüşle ortadan kaldırıldığı görülmektedir. Nitekim uzmanlık alanı PDR olan günümüz ME Bakanı'nın, 2017 yönetmeliğinden bir yıl sonra, 11. Kalkınma Planı (2019-2023) kapsamında açıkladığı̆, Güçlü Yarınlar İçin 2023 Eğitim Vizyonu belgesinde, 2017 yönetmeliğindeki aksaklıkları giderme iradesi ortaya koyduğu ve bu bağlamda, 2017 yönetmeliğinde kullanılan kavramlardan farklı biçimde, işlevsel bir PDR yapılanması önerdiği görülmektedir (MEB, 2019). Güçlü Yarınlar İçin 2023 Eğitim Vizyonu belgesinde, "hâlen tüm öğrenciler için işlevsel bir yönlendirme mekanizmasının mevcut olmayışı" nedeniyle, bu düzenlemeye gerek duyulduğu belirtilerek başlangıçtan beri kalkınma planlarında öne çıkan yöneltme amacı her zamanki gibi desteklenmektedir. Ancak, son PDR yönetmeliğine yönelik eleştirilerle birleşen bir biçimde, "PDR hizmetlerinin eğitim sistemindeki yeri, yapısı, işlevleri ve mevzuat alt yapısı yeniden düzenlenmesi gerekmektedir" ifadelerine yer verilmiştir. Burada, Milli Eğitim Bakanlığı'nın okul PDR hizmetlerine bakışında, kendi bakanlığının önceki çalışmalarıyla (yönetmelikler, şûralar) uyuşmama şeklinde paradoksal bir durum gözlenmektedir.

Sonuç olarak, MEB'in okul PDR hizmetlerine bakışında, kalkınma planlarındaki PDR kararlarına da, önceki bazı şûra kararları ve yönetmelik düzenlemelerinde ortaya koyduğu açılımlara da her zaman sahip çıkmayan bir tutum ortaya çıktığı söylenebilir. PDR hizmetlerini yöneltme ile eş anlamda sayan bir bakıştan; günümüzde, PDR hizmetlerini eğitsel çalışmalar ve sınıf öğretmenliği ile aynı program içine yerleştiren bir anlayışa kadar gelinebilmiştir. PDR alanını bu sınırlı konumlanmadan kurtaracak, psikolojik danışma ve rehberlik ile diğer tüm kişilik hizmetlerini kapsayan bir anlayış çerçevesinde, modern PDR hizmetleri esaslarına uygun ve uygulamadaki aksaklıkları giderecek biçimde örgütlenmesini sağlayacak düzenlemelere ihtiyaç vardır. PDR alanının amaç ve işleyişi konusundaki düzenlemelerin, ME şûra kararlarının ve kalkınma planı hedeflerinin, birbirleriyle ve çağdaş yaklaşımlarla uyumlu bir ortak anlayışla geliştirilmesi önemlidir. Bakanlığın, yürürlüğe koyduğu yönetmelikler ve düzenlediği şuralar, PDR alanının çağdaş yaklaşımlarıyla uyumlu bir felsefe temeline dayandırılmalıdır. Yapılan her düzenlemede, önceki çalışmalara ve bilimsel ölçütlere göre alınmış olan kararlara duyarlı, gelişimsel bir sürdürebilirlik tutumu sergilemek gerekmektedir. Böyle bir tutumun neden ortaya konulamadığı araştırılmalıdır. Bu çalışmadan hareketle, kalkınma planları ve eğitim şuralarında alınan kararların yürürlüğe konulmasını engelleyen faktörlerin neler olduğu bilimsel 
araştırma konusu olarak ele alınabilir. Öte yandan, bu araştırma, PDR yönetmeliklerine odaklı bir yaklaşımla ele alındığından, tüm kalkınma planlarını kapsamamıştır. Tüm kalkınma planları ve bu süre içerisinde çıkarılan PDR ile ilgili tüm yönetmelik ve yönergeler kapsamlı bir şekilde araştırılabilir ve birbirlerine göre gelişimsel seyri irdelenebilir. Önümüzdeki dönem kalkınma planı ve 2023 Vizyon Belgesi çalışmaları da PDR alanına ilişkin kararları ve uygulamaya yansımaları açısından incelenebilir.

PDR hizmet alanının eğitimdeki önemine rağmen sorunları çok ve çeşitlidir. Eğitim sistemi içinde PDR alanı, felsefe, yaklaşım, örgüt, program, işleyiş ve personel açılarından birçok temel sorununu çözecek yeterlikte düzenlemelere ihtiyaç duyan bir hizmet grubu görünümündedir. Bu çalışmanın analiz bulguları, MEB'in PDR alanına yönelik düzenlemelerinin, önceki planlama ve düzenleme çalışmalarını geliştirmeye ve alanın güncel ihtiyaçlarına karşılık vermeye yönelik olması gereğine dikkat çekmektedir.

\section{Yazar(lar)ın Beyanı}

Araştırmacıların katkı oranı beyanı: Araştırmanın verileri doğrudan birinci yazar tarafından toplanmıştır. Her iki yazar, araştırmanın giriş, yöntem, bulgular, tartışma ve sonuç bölümlerine katkıda bulunmuştur.

Etik Kurul Kararı: Bu çalışma etik kurul kararı gerektirmemektedir.

Çatışma beyanı: Araştırmada, yazarların kendi içinde ve diğer kişi/kurum/kuruşlarla herhangi bir çıkar çatışması söz konusu değildir.

Destek ve teşekkür: Araştırmanın yürütülmesinde herhangi bir kurumdan destek alınmamıştır.

\section{Kaynaklar}

Akay, S., Türk, F., Mercan, Ö. ve Urtekin, F. (2019). Psikolojik danışmanların bakış açısından Rehberlik Hizmetleri Yönetmeliği'nin incelenmesi. İnönü Üniversitesi Ĕ̆itim Fakültesi Dergisi, 20(3), 891-918.

Altheide, D. (1996). Process of document analysis. D. Altheide (Ed.), Qualitative media analysis (s. 23-41) içinde. Thousand Oaks: Sage Pub.

Altundemir, M. E. (2012). Kalkınma planlarından eğitime bakış: Kamusal mallar teorisi perspektifinden. Bilgi Ekonomisi ve Yönetimi Dergisi, 7(1), 94-105.

Çoruk, A. (2019). Planlı kalkınma dönemindeki milli eğitim şûra kararlarının kalkınma planlarındaki eğitime ilişkin hedefler çerçevesinde değerlendirilmesi. Eğitimde Kuram ve Uygulama, 15(4), 297-318.

Dağhan, G., Kalaycı, E. ve Seferoğlu, S. S. (2011, Şubat). Milli Eğitim Şûralarındaki teknoloji politikalarının incelenmesi. XIII Akademik Bilişim Konferansı. Malatya, Türkiye.

Dağll, S. (2014). Rehber öğretmen ve psikolojik danışmanların kendi mesleklerine ilişkin algıları üzerine nitel bir araştırma (Yayımlanmamış doktora tezi). İstanbul Üniversitesi, İstanbul.

Doğan, S. (1991). Başlangıcından bugüne Türk resmi dokümanlarında rehberlik kavramı ve anlayışı: Bir inceleme. Türk Psikolojik Danışma ve Rehberlik Dergisi, 1(2), 29-44.

Eğitim-Sen. (2017). 15.07.2020 tarihinde http://egitimsen.org.tr/yeni-rehberlik-hizmetleri-yonetmeligi-buyukhayal-kirikligi-yaratmistir adresinden erişildi.

Glesne, C. ve Peshkin, A. (1992). Becoming qualitative researchers: An introduction. White Plains, NY: Longman.

Gümüş, A. E. (2018). Yeni rehberlik hizmetleri yönetmeliğinin bir etik dışı dayatmasına yönelik çözüm önerileri. Okul Psikolojik Danışmanı E-Bülteni, 8, 5-7.

Güven, M., Alagöz Hamzaj, Y. ve Baldan, B. (2016). Milli Eğitim Şûraları kararlarında ve kalkınma planlarında öğretmenlerin hizmet içi eğitimi. Sosyal Bilimler Dergisi, 3(9), 39-56.

Halmatov, S. (2014). Türkiye'de psikolojik danışma ve rehberliğin gelişim süreci (Yayımlanmamış doktora tezi). Atatürk Üniversitesi, Erzurum. 
Karasar, N. (2007). Bilimsel araştırma yöntemleri (17. bs. ) Ankara: Nobel Yayıncılık.

Korkut, F. (2007). Psikolojik danışmanların mesleki RPD ile ilgili düşünceleri ve uygulamaları. Hacettepe Üniversitesi Eğitim Fakültesi Dergisi, 32(32), 187-197.

Küçüker, E. (2012). Türkiye'de kalkınma planları kapsamında yapılan eğitim planlarının analizi. Kastamonu Eğitim Dergisi, 20(1), 9-26.

Maxwell, J. A. (1992). Understanding and validity in qualitative research. Harvard Educational Review, 62(3), 279-300.

MEB. (1970). Orta dereceli okullarda rehberlik servislerinin kuruluşu ve görevleri ile ilgili bazı esaslar. Tebliğler Dergisi, 33(1619), 293-298.

MEB. (2019). 2023 Ĕ̆itim Vizyonu. Erişim adresi: http://2023vizyonu.meb.gov.tr/

MEB İlköğretimde Yöneltme Yönergesi. (2003). Tebliğler Dergisi (Sayı:2552). Erişim adresi: http://mevzuat.meb.gov.tr/dosyalar/285.pdf

$\begin{array}{lllll}\text { MEB } & \text { Milli Şurası. (1970). Eğitim } & \text { Erişim } & \text { adresi: }\end{array}$ https://ttkb.meb.gov.tr/meb_iys_dosyalar/2017_09/29165001_8_sura.pdf

MEB Milli Sğitim Şurası. (1988). Erişim https://ttkb.meb.gov.tr/meb_iys_dosyalar/2017_09/29165252_12_sura.pdf

MEB Rehberlik Hizmetleri Yönetmeliği. (2017, 10 Kasım). Resmi Gazete (Sayı: 30236) Erişim adresi: https://www.resmigazete.gov.tr/eskiler/2017/11/20171110-2.htm

MEB Rehberlik ve Araştırma Merkezi Yönetmeliği. (1968, 31 Ocak). Resmi Gazete (Sayı:12814) Erişim adresi: https://www.resmigazete.gov.tr/arsiv/12814.pdf

MEB Rehberlik ve Psikolojik Danışma Hizmetleri Yönetmeliği. (2001). Erişim adresi: http://tebligler.meb.gov.tr/index.php/tuem-sayilar/viewcategory/65-2001

Nas, E. (2018). Rehber öğretmenlerin yeni rehberlik hizmetleri yönetmeliğine ilişkin algıların incelenmesi. Adnan Menderes Üniversitesi Ĕ̆itim Fakültesi Ĕ̆itim Bilimleri Dergisi, 9(2), 109-118.

Özyürek, R. (2007). Psikolojik danışman eğitiminin ve okullardaki PDR hizmetlerinin niteliğini yükseltmeye yönelik öneriler. Özyürek, R., Korkut, F. ve Korkut, D. O. (Ed.), Gelişen psikolojik danışma ve rehberlik (s. 123-139) içinde. Ankara: Nobel Yayın Dağıtım.

Paksoy, E. E. (2011, Ekim). Milli Eğitim Ş̂̂ra kararlarının uygulanabilirliğinin kalkınma planları üzerinden değerlendirilmesi: Mesleki eğitim açısından bir inceleme. II. Eğitim Yönetimi Forumu, Ankara, Türkiye.

Pişkin, M. (2006). Türkiye'de psikolojik danışma ve rehberlik hizmetlerinin dünü, bugünü ve yarını. Hesapçığlu, M. ve Durmuş, A. (Ed.), Türkiye'de eğitim bilimleri bir bilanço denemesi (s. 458-501) içinde Ankara: Nobel Yayın Dağıtım.

Roberts, P., Priest, H. ve Traynor, M. (2006). Reliability and validity in research. Nursing Standard, 20(44), 4145.

Şahin, F. Y. (2012). Türk Milli Eğitim Şûralarında (1939-2010) psikolojik danışma ve rehberlik ile ilgili alınmış olan kararların değerlendirilmesi. Sosyal Bilimler Eğitimi Araştırmaları Dergisi, 3(1), 95-118.

Şişman, M. ve Taşdemir, İ. (2008). Türk eğitim sistemi ve okul yönetimi. Ankara: Pegem.

Tan, H. (1990). Okullarımızda psikolojik hizmetlerin neresindeyiz?. Türk Psikolojik Danışma ve Rehberlik Dergisi, $1(1), 27-31$.

Taş, U. (2007). Türkiye'de Kalkınma Planları ışı̆̆ııda eğitimin kalkınmadaki rolü (Yayımlanmamış yüksek lisans tezi). Eskişehir Osmangazi Üniversitesi, Eskişehir. 
T.C. Başbakanlık Devlet Planlama Teşkilatı. (1984). Beşinci Beş Yıllık Kalkınma Planı (1985-1989). 12 Ağustos 2020 tarihinde http://www.sbb.gov.tr/kalkinma-planlari/ adresinden erişildi.

T.C. Başbakanlık Devlet Planlama Teşkilatı. (2000). Sekizinci Beş Yıllık Kalkınma Planı (2001-2005). 12 Ağustos 2020 tarihinde http://www.sbb.gov.tr/kalkinma-planlari/ adresinden erişildi.

T.C. Başbakanlık Devlet Planlama Teşkilatı Müsteşarlığı. (1968). İkinci Beş Yıllık Kalkınma Planı (1968-1972). 12 Ağustos 2020 tarihinde http://www.sbb.gov.tr/kalkinma-planlari/ adresinden erişildi.

T.C. Kalkınma Bakanlığı. (2013). Onuncu Kalkınma Planı (2014-2018). 12 Ağustos 2020 tarihinde http://www.sbb.gov.tr/kalkinma-planlari/ adresinden erişildi.

Tofur, S., Aypay, A. ve Yücel, C. (2016). 1980 - 2014 Türk milli eğitim şûra kararları ile tebliğler dergisi fihristlerinin karşılaştırmalı değerlendirilmesi. Eğitim ve Bilim, 41(186), 253-274.

Tuzgöz, M. ve Keklik, İ. (2012). Alanda çalışanların gözünden psikolojik danışma ve rehberlik alanının sorunları. Mehmet Akif Ersoy Üniversitesi Ĕ̆itim Fakültesi Dergisi, 12(23), 389 - 407.

Üstüner, V. (2018). Yeni yönetmeliğe eleştirel bakış. Okul Psikolojik Danışmanı E-Bülteni, 8, 23-25.

Yıldırım, A. ve Şimşek. H. (2006). Sosyal bilimlerde nitel araştırma yöntemleri. Ankara: Seçkin Yayıncllık.

Yıldız, O. ve Yıldız, T. (2016). Türkiye Cumhuriyeti eğitim politikaları. Journal of Research in Education and Society, 3(1), 24-41. 


\section{EXTENDED ABSTRACT}

\section{Introduction}

In this study, it was aimed to answer the question of to what extent Psychological Counselling and Guidance services are compatible with the decisions in the development plans of the period it is in. Within the scope of the study, the school Psychological Counselling and Guidance services regulations, the related development plans and Ministry of National Education (MNE) councils made in the same period, the purpose and job descriptions of the Guidance and Councelling profession were examined, and their compatibility with each other was examined through the similarities and differences in their approaches. Psychological Counselling and Guidance regulations and MNE councils put into effect by the Ministry of National Education until today have been discussed in relation to the plans of the development period they are in, and the harmony between them has been questioned. It has been examined how the decisions taken regarding school Psychological Counselling and Guidance services in the development plans are reflected in the regulations (regulations and council decisions) made in that development period. For example, the 1985 Guidance Services Regulation came into force during the Fifth Five-Year Development period (1985-1989). It was carried out in the 12th MNE Council (18-22 June 1988) within the same development period. In this context, the Fifth FiveYear Development Plan, 1985 Regulation and the twelfth MNE Council have been analyzed comparatively from the perspective of Psychological Counselling and Guidance services.

\section{Method}

In the study, document analysis method was used. Descriptive analysis was conducted in the form of presenting the data in a summarized and interpreted form, including quotations. Development plans and decisions related to regulations are tabulated and compared. In this study, four Psychological Counselling and Guidance regulations that have been published until today and the development plans within the time frame that includes the date of entry into force of these regulations are discussed. In this context, among a total of eleven development plans prepared since 1963, four development plans including the publication date of the Psychological Counselling and Guidance regulations have been examined. As data sources, the Psychological Counselling and Guidance services regulations issued until today and the texts of the Five-Year Development Plans, including the year they came into force, were used. The MNE has published a total of four regulations on the organization, management and execution of Psychological Counselling and Guidance services to date. Four development plans covering the years in which these regulations entered into force were included in this study. ME councils, if any, were included in the review during the development period under consideration.

\section{Findings and Discussion}

As a result, it is difficult to say that the regulations and councils of the Ministry of National Education regarding school Psychological Counselling and Guidance services are sensitive to the decisions of development plans, but in line with the previous planning and regulation studies made by their ministry, supportive and observing the unity of concept. The findings of the study draw attention to the necessity of changing the policies of the Ministry of National Education in the field of Psychological Counselling and Guidance in a direction to eliminate this negativity. The regulations put into effect by the Ministry and the councils it organizes should be based on a philosophy that is compatible with the contemporary approaches of the Psychological Counselling and Guidance field. In every regulation, it is necessary to display a developmental sustainability attitude that is sensitive to previous studies and decisions made according to scientific criteria. It should be investigated why such an attitude could not be revealed. Based on this study, the factors that prevent the implementation of the decisions taken in development plans and education councils can be considered as a scientific research subject. On the other hand, since this research is focused on Psychological Counselling and Guidance regulations, it did not cover all development plans. Psychological Counselling and Guidance decisions in a total of 11 development plan dates can be investigated comprehensively and their developmental course with respect to each other can be examined. The upcoming development plan and 2023 Vision Document studies can also be examined in terms of the decisions and implications for the Guidance and Councelling field. 